\title{
DESIGNING MIGRATION CORRIDORS FOR LARGE MAMMALS IN THE CZECH REPUBLIC
}

\author{
DUŠAN ROMPORTL ${ }^{1,2^{*}}$, MiCHAL ANDREAS ${ }^{1}$, PETR ANDĚL $^{3}$, ANNA BLÁHOVÁ $^{1}$, \\ LUDĚK BUFKA ${ }^{5}$ IVA GORČICOVÁ $^{3}$, VÁCLAV HLAVÁČ ${ }^{4}$, TEREZA MINÁRIKOVÁ ${ }^{4}$, \\ MARTIN STRNAD ${ }^{4}$
}

${ }^{1}$ Silva Tarouca Research Institute for Landscape and Ornamental Gardening, Květnové náměstí 391, 25243 Průhonice*dusan@natur.cuni.cz.

${ }^{2}$ Department of Physical Geography and Geoecology, Faculty of Science, Charles University in Prague, Albertov 6, 12843 Praha 2

${ }^{3}$ EVERNIA, s.r.o; Tř́lda 1. máje 97, 46001 Liberec

${ }^{4}$ Agency for Nature Conservation and Landscape Protection of the CR, Nuselská 39, 140 OO Praha 4

5 The Administration of Šumava NP and PLA, Sušická 399, 34192 Kašperské Hory

Received: $9^{\text {th }}$ August 2012, Accepted: $25^{\text {th }}$ March 2013

\begin{abstract}
The presented article introduces methods and some results of a project aiming to improve the protection of landscape permeability for migration of large mammals. The main aim of the project was delimitation of migration corridors, representing an ecological network connecting areas of existing, or potential presence of focal species. Based on mapping of current and historical occurrence of selected species of large predators and ungulates, areas of potential presence of such species were defined, including further analysis of connectivity of these areas. At the same time, all categories of anthropogenic and natural barriers were described. Migration corridors were designed over detailed topographic datasets, according to the results of habitat analyses of both groups of animals, and subsequently were tested in the field. The project resulted in a coherent network of existing and proposed migration corridors, with sections categorised according to permeability, as well as methodical protection and a management plan.
\end{abstract}

Key words: Migration, large mammals, habitat suitability models, wildlife corridors, migration barriers, landscape connectivity

\section{INTRODUCTION}

Landscape fragmentation represents one of the most serious threats to biodiversity (Pimm et al., 1995, Schipper et al., 2008). Historical development of land use in Central Europe caused high landscape heterogeneity, and current trends lead to its further fragmentation (Feranec et al., 2010, Jongman, 2002). Processes of land-use intensification and landscape fragmentation through linear barriers result in decreased connectivity of habitats suitable to permanently support large species of mammals (Kramer-Schadt et al., 2004, Huck et al., 2010). Large predators, namely the Eurasian Lynx (Lynx lynx), Wolf (Canis lupus lupus) 
and Brown Bear (Ursus arctos arctos), and herbivores such as the Eurasian Elk (Alces alces) possess large territorial requirements. However, they occur within isolated fragments of suitable habitat of various sizes, and are therefore forced to migrate. Migration of large mammals represents a specific ecological phenomenon when some individuals, respectively a part of population leave their former home ranges (either their own or those of their parents) to travel large distances. This phenomenon is no longer typical only for the vast and little changed natural habitats; it takes place in the mosaic landscape of Central Europe. Landscape structure and the level of its fragmentation through anthropogenic activities constitute key factors dictating the character, intensity and success rate of migration (Horskins et al. 2006). It is not surprising that decreasing connectivity of suitable habitats, with an increasing barrier effect of linear structures, critically delimitate the former functional connectivity of individual areas of occurrence of target species in the recent decades. Interconnection of local populations is crucial for preserving the viability of target species groups, as well as for the necessary preservation of genetic diversity according to the metapopulation theory. A number of European countries realise the severity of this problem, and have designed networks of migration corridors with a certain level of landscape protection (i.e. Van der Sluis ed., 2004, Bruinderink et al., 2003). However, not enough attention has been paid to long distance migration routes of large mammals in the Czech Republic. The main reasons for this were lack of scientific knowledge on ecological requirements of migrating individuals, not satisfying coordination between the nature conservation bodies involved as well as investors, mainly in transportation structures, and persons responsible for territorial planning.

A solution to these problems and a proposal of suitable measures were amongst the main targets of the project "SP2d4 Evaluation of migration permeability of landscape for large mammals and proposal of protection and optimisation measures" (Andreas et al., 2007). The main scientific aim of the project was delimitation of real, as well as potential, migration corridors for large mammals, within the territory of the Czech Republic. This included securing the connectivity to ecological networks from the neighbouring countries, based on the current scientific knowledge on occurrence and character of migration of target species. The project also attempted to propose suitable conservation and long-term sustainability of the delimitated corridors. This applied target represents the main problem from the consensus of all involved scientific groups and institutions. From the point of view of protection of interconnectivity of zoogeographical zones, it appears to be a logical solution to design an independent network of core areas interconnected by migration corridors. This faces numerous legislative as well as administrative obstacles; therefore, a possible solution appears to be the implementation of the designed migration corridors into the Territorial System of Ecological Stability, whilst updating its supra-regional level.

\section{METHOdS}

The process of designing existing and potential migration corridors consists of several sequential steps. Current and historical data on occurrence of target species of large mammals were analysed and their habitat requirements were evaluated in the first phase. Behaviour of migrating individuals was observed with the aid of camera traps, positioned at crossing points along linear barriers, in order to analyse ethological indicators in stress situations. Furthermore, data on barrier as well as supportive landscape elements were analysed, and all relevant environmental variables forming the character and intensity of migration were evaluated. 
Regarding the analyses of these data, core areas of actual or potential occurrence of target species were delimited and interconnected by a network of general migration directions. A crucial step of the process of corridor design was field mapping of migration routes across the whole territory of the Czech Republic. When proposing the corridors, the connectivity with networks of neighbouring countries was ensured. The final step of methodical process is a proposal of migration corridors connecting core areas, and a methodical order to support their conservation.

\section{Data analysis of target species}

The starting point for research of migration requirements of target species was the analysis of all existing data on their historical, as well as current, occurrence. The basic source of information were Database on species occurrence for nature conservation of the Agency for Nature Conservation and Landscape Protection (NDOP AOPK) and faunistic datasets of Management of National Parks and Protected Landscape Areas, in which mainly information on occurrence of specially protected target species are kept (such as Eurasian Lynx, Bear, Wolf and Elk). Occurrence data of predators are in most cases exactly localised, and therefore it is possible to connect further detailed information on the character of the environment to the site. However, an otherwise high quality dataset does not, in the case of ungulate species, contain sufficiently detailed data. Results of questionnaire surveys were therefore processed (Anděra and Hanzal, 1995, Anděra and Červený, 2009). In order to express accuracy of target species occurrence, the results of questionnaires collected with regard to individual game keeping organisations correlated only to individual game keeping areas, respectively cadastres. As a result of the research, a summary of datasets of various spatial expression and scale was produced, which were also used as a basis for analysis of spatial requirements of the focal species. The cartographic expression of the recent occurrence of target species is described in Figures $1-5$.

Fig. 1: Map of occurrence of Eurasian Lynx (Lynx lynx) after 1985 in the Czech Republic

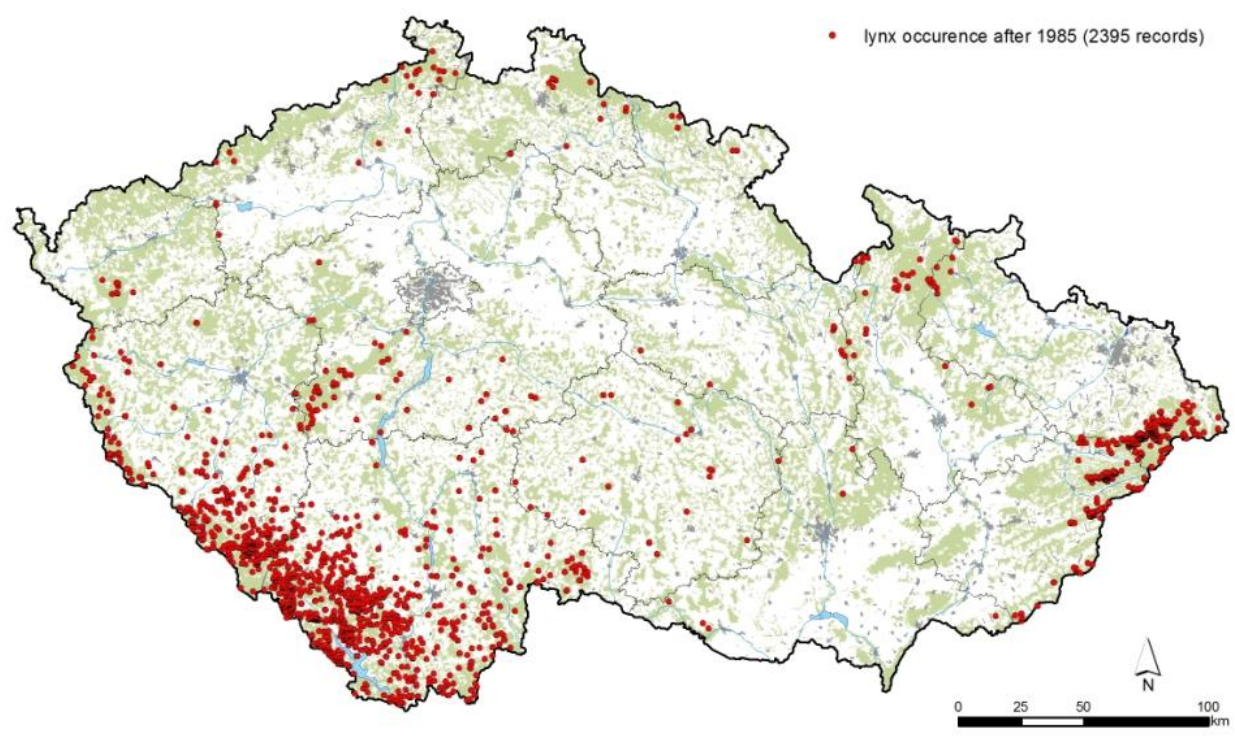


Fig. 2: Map of occurrence of Eurasian Wolf (Canis lupus lupus) after 1985 in the Czech Republic

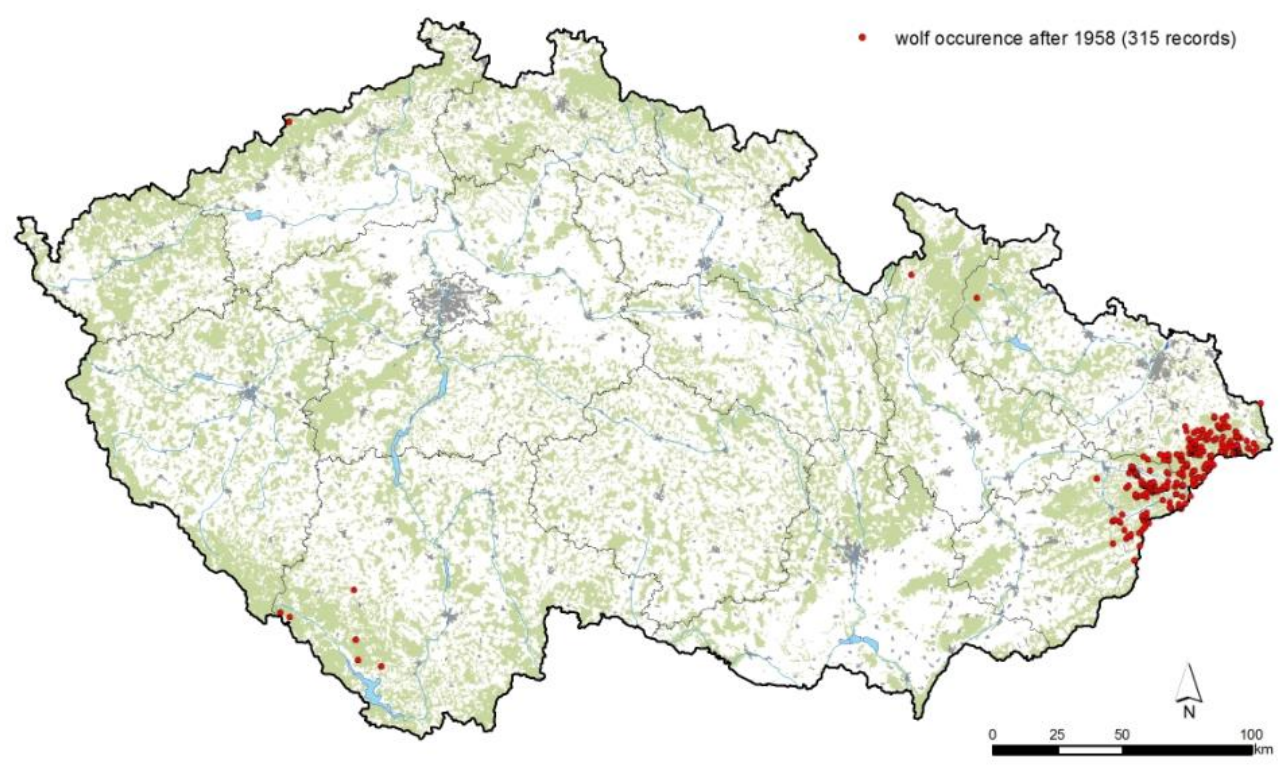

Fig. 3: Map of occurrence of Eurasian Brown Bear (Ursus arctos arctos) after 1985 in the Czech Republic

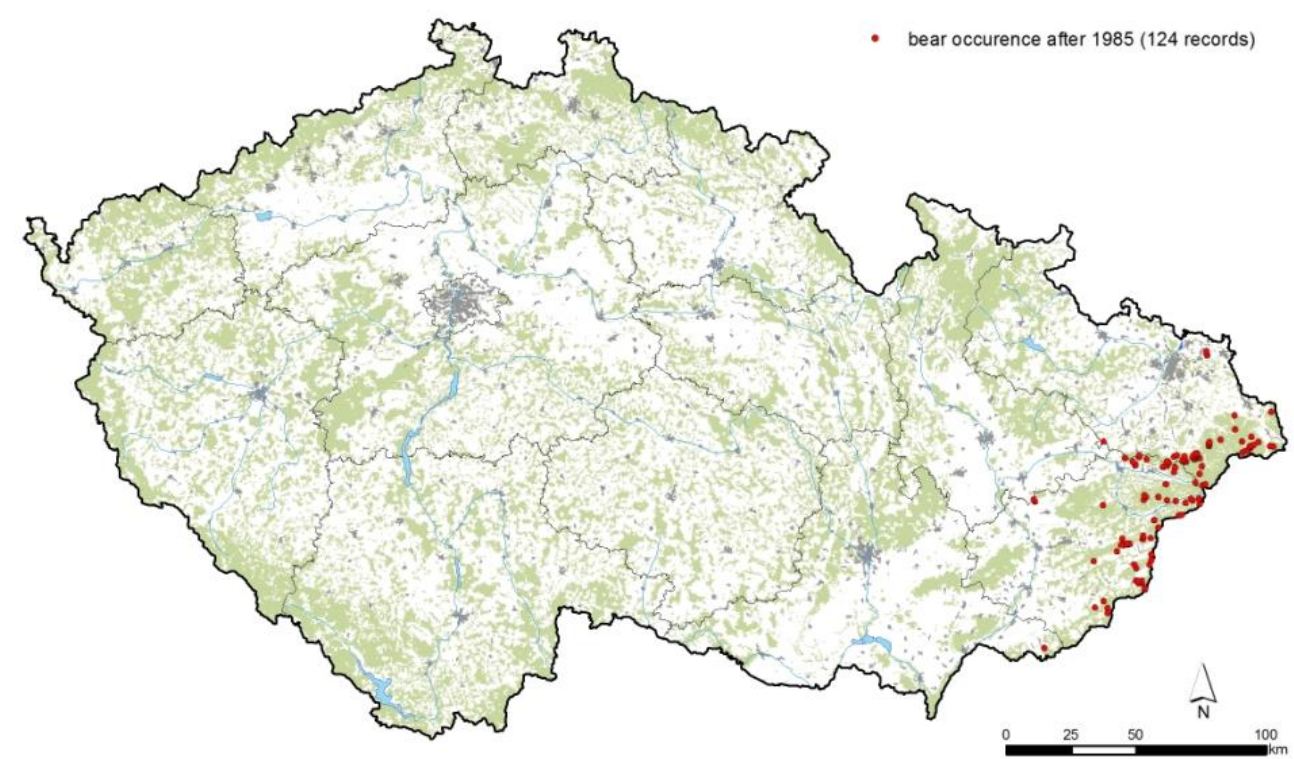


Fig. 4: Map of occurrence of Red Deer (Cervus elaphus) after 2006 in the Czech Republic

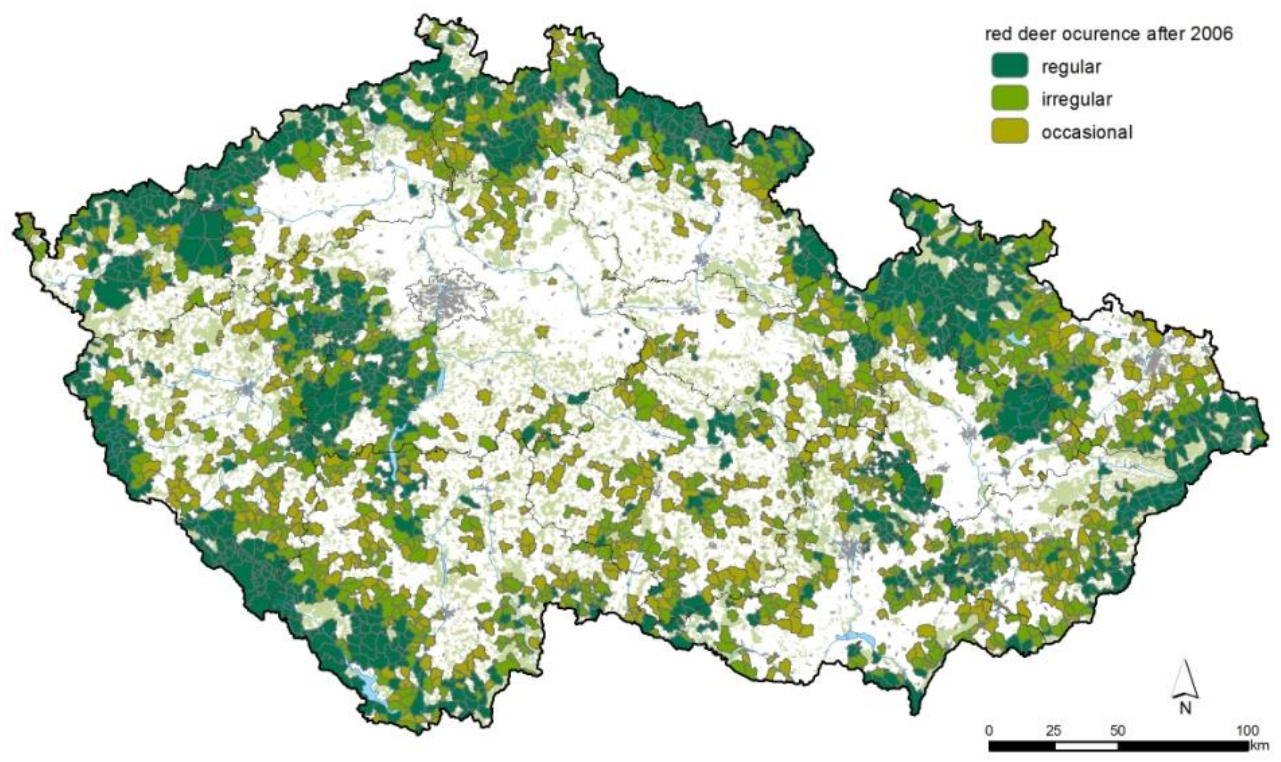

Fig. 5: Map of occurrence of Eurasian Elk (Alces alces) after 2006 in the Czech Republic

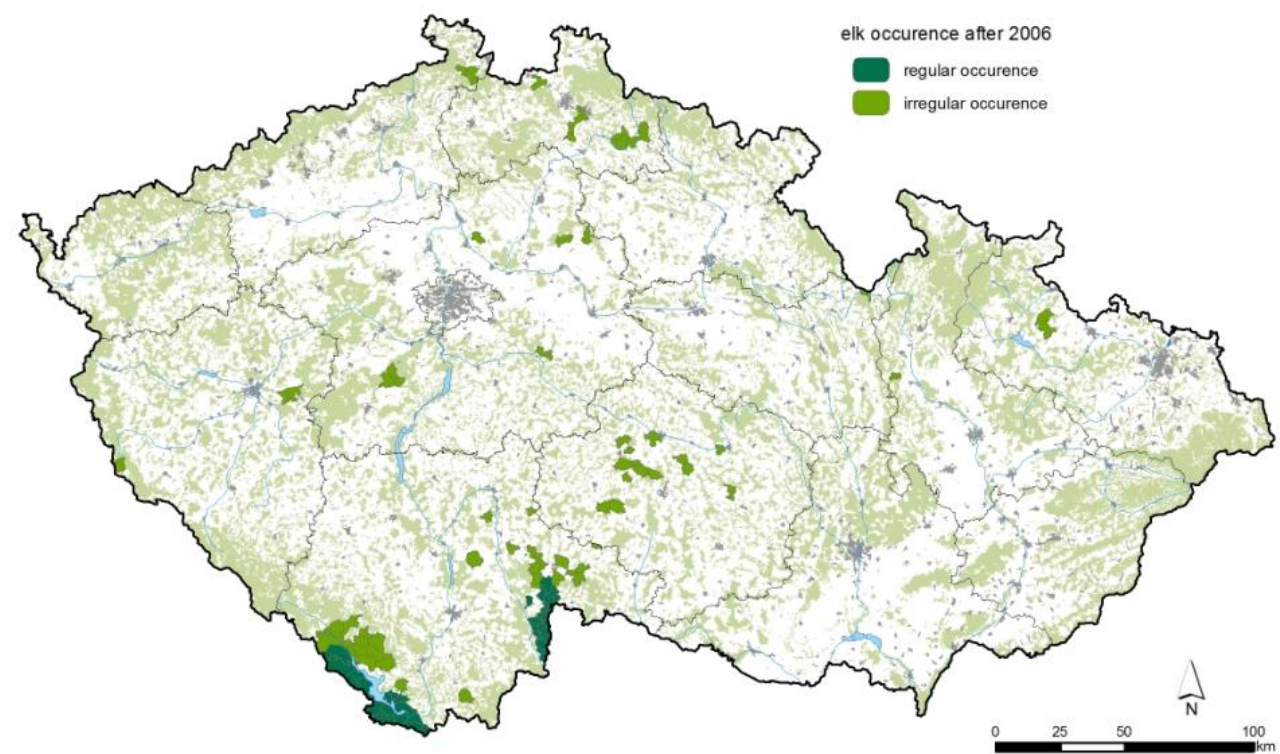




\section{Observation of behaviour of migrating individuals}

An important part of the project was observation and evaluation of behaviour of migrating individuals, in places of crossing barriers of linear character. Camera-traps have been installed on six selected crossing under the D5 motorway between Prague and Rozvadov. These are potentially important crossing corridors from the point of view of ungulates migration. Over 8,000 photographs and video sequences were taken in 2009; however, animals were only captured on 136 video recordings and several photographs. A significant majority of ungulates crossing were captured during October (86 records). The higher number of records can be partially explained by optimisation of the position of cameras, but is definitely related to the annual migration cycle of the target species of undulates. From the research carried out so far it is obvious that motorway crossings are less used by game than predicted (Wieren et al., 2001). Despite the low number of records, the method brought surprising results about the relatively frequent usage of underpasses of small size mainly in agricultural landscapes. At the same time a relatively high intensity of people and vehicles was recorded in larger underpasses, which reduces the probability of game to be using the same underpasses.

\section{Analysis of anthropogenic barriers in landscape}

The main processes leading to higher fragmentation of areas suitable for permanent occurrence of target species are considered as follows (Hlaváč and Anděl, 2001, Iuell et al., 2003):

- $\quad$ Agricultural intensification (large areas of monocultures, fenced pastures, etc.)

- Industry and mining (construction of industrial zones, mining and wasteland)

- Growth of sub/urban areas (residential - satellite cities, urban sprawl, commercial suburbanisation - construction of large shopping, logistic and entertainment centres)

- $\quad$ Construction of transport infrastructure (motorways, roads, railways)

The most detrimental fragmentation effect is considered to be the construction of transport lines, mainly because this creates long barrier lines that are impossible to cross by animals. Especially highly frequented transport lines such as motorways and high speed roads, whose density keeps growing in the landscape, form significant and often impassable barriers for the movement of many animals (Hlaváč and Anděl, 2001, Iuell et al., 2003).

Above all, ecological and ethological parameters of migration behaviour of species of interest were considered while defining barriers within the landscape. These parameters were deduced from several habitat analyses based on telemetric studies, and observation of individuals crossing barriers using camera-traps.

Existing and potential migration routes of target species have to overcome a number of barrier types. In order to categorise the designed corridors, it is necessary to evaluate how difficult is it to cross the barrier, whether it is a crucial place with impassable barriers or a place that is crossable with small disturbance. Each section of a migration corridor is evaluated and categorised according to the significance of a barrier. The scale of evaluation is summarised in the following table: 
Table 1: Basic categories of evaluation of migration corridors permeability

\begin{tabular}{|l|l|l|}
\hline Section of migration corridor & Symbol & Evaluation of permeability \\
\hline \multirow{3}{*}{ Existing barriers } & $\mathrm{K} 1$ & Completely non-permeable barrier \\
\cline { 2 - 3 } & $\mathrm{K} 2$ & Significant barrier \\
\cline { 2 - 3 } & $\mathrm{K} 3$ & Medium level barrier \\
\hline \multirow{2}{*}{ Permeable area } & $\mathrm{P}$ & Permeable point (low disturbance) \\
\cline { 2 - 3 } & $\mathrm{PZ}$ & Completely permeable point (no barrier) \\
\hline
\end{tabular}

\section{Categories of main types of barriers:}
A. Roads and motorways network
B. Railway network
C. Streams and water bodies
D. Fencing
E. Urbanised areas
F. Non-forest areas

\section{A. Roads and motorways network}

The transport network was classified according to the intensity of impact, as well as the character of technical modifications, based on the data of Headquarters of Roads and Motorways. Main sections of the barrier effect are categories of transport lines, technical solutions and the intensity of traffic.

Table 2: Classification of Motorways and Roads

\begin{tabular}{|c|c|c|c|}
\hline \multicolumn{4}{|c|}{ Motorways and Roads } \\
\hline Class & Category & Technical solution & $\begin{array}{l}\text { Intensity of } \\
\text { traffic }\end{array}$ \\
\hline K1 & $\begin{array}{l}\text { Motorways and } \\
\text { highways }\end{array}$ & $\begin{array}{l}\text { Total mechanic barriers (steep slopes and } \\
\text { cuttings, acoustic walls, supports, stone } \\
\text { walls, etc.) }\end{array}$ & $\begin{array}{l}\text { More than } 30,000 \\
\text { vehicles/day }\end{array}$ \\
\hline $\mathrm{K} 2$ & $\begin{array}{l}\text { Other multi-lane } \\
\text { roads }\end{array}$ & $\begin{array}{l}\text { Significant technical barriers, high } \\
\text { embankments and cuttings that can be } \\
\text { partially permeable) }\end{array}$ & $\begin{array}{l}10,000 \text { to } 30,000 \\
\text { vehicles/day }\end{array}$ \\
\hline $\mathrm{K} 3$ & $\begin{array}{l}\text { Other I. class } \\
\text { roads }\end{array}$ & $\begin{array}{l}\text { Transport line with permeable mechanic } \\
\text { barriers (middle or side crash barrier) }\end{array}$ & $\begin{array}{l}5,000 \text { to } 10,000 \\
\text { vehicles/day }\end{array}$ \\
\hline $\mathrm{P}$ & Local roads & No technical barriers & $\begin{array}{l}\text { Less than 5,000 } \\
\text { vehicles/day }\end{array}$ \\
\hline $\mathrm{PZ}$ & No roads & & \\
\hline
\end{tabular}

If there is a bridge or underpass in the crossing with a potential corridor, it is necessary to consider its potential utilisation by migrating wildlife, and the overall evaluation of such a critical point has to be adjusted. It is possible to use the Technical Conditions Guidelines, reg. number TP 180 - Migration structures for ensuring permeability of motorways and roads for wildlife, published by the Ministry of Transport in 2006, in order to evaluate such structures. 


\section{B. Railway Networks}

Railway networks are classified according to components of the barrier effect categories of railway and technical solutions - into five basic categories. In the final solution it is necessary to evaluate the presence and character of migration structures, similarly to roads.

Table 3: Classification of Railways

\begin{tabular}{||l|l|l||}
\hline \hline Railways & Technical Solution \\
\hline Class & Category of railway & $\begin{array}{l}\text { Railways with steep slopes and cuttings or with other } \\
\text { technical barriers which are non-permeable for } \\
\text { mechanic reasons }\end{array}$ \\
\hline K2 & $\begin{array}{l}\text { Main transit corridors, } \\
\text { multi-track railways }\end{array}$ & $\begin{array}{l}\text { Railways with significant mechanic barriers which } \\
\text { can be partially permeable }\end{array}$ \\
\hline K3 & Regional railways & Railways with less significant terrain modifications \\
\hline P & $\begin{array}{l}\text { Local, less frequented } \\
\text { railways }\end{array}$ & Railways in flat terrain with no barriers \\
\hline PZ & No railways & \\
\hline
\end{tabular}

\section{Streams and Water Bodies}

Spatial position of water bodies and streams was derived from the topographic database ZABAGED (ČÚZAK 2009). The main components of the barrier effect are the extent of a water surface, respectively the width and technical solution restricting crossing.

Table 4: Classification of Streams and Water Bodies

\begin{tabular}{||l|l|l||}
\hline \hline Streams and Water Bodies \\
\hline Class & Size of water body & Technical solution \\
\hline K1 & Width greater than $500 \mathrm{~m}$ & $\begin{array}{l}\text { Streams with technically regulated (reinforced) } \\
\text { banks that completely prevent crossing }\end{array}$ \\
\hline K2 & Width $200-500 \mathrm{~m}$ & $\begin{array}{l}\text { Streams with significant technical barriers that can } \\
\text { be partially permeable }\end{array}$ \\
\hline K3 & Width $100-200 \mathrm{~m}$ & $\begin{array}{l}\text { Streams and water bodies with less extensive } \\
\text { regulations of banks }\end{array}$ \\
\hline P & Width less than $100 \mathrm{~m}$ & Streams and water bodies with natural banks \\
\hline PZ & No water bodies & \\
\hline
\end{tabular}

\section{Fencing}

Geographical distribution and localisation of fencing is not possible to define solely with the use of orthophoto maps; therefore their position had to be surveyed in the field. A clue for their potential position was distribution of vineyards, hop fields, as well as grassland as potential pastures. These types of land cover were derived from the CORINE Land Cover 2006 dataset (EEA 2009). The main elements of barrier effect are the technical solution of fencing and the width of non-obstructed passage between fencing. 
Table 5: Classification of Fencing

\begin{tabular}{|c|c|c|}
\hline \multicolumn{3}{|c|}{ Fencing } \\
\hline Class & $\begin{array}{l}\text { Distance between } \\
\text { fences }\end{array}$ & Technical solution of fencing \\
\hline$\overline{\mathrm{K} 1}$ & Up to $10 \mathrm{~m}$ & $\begin{array}{l}\text { Permanent, tall (more than } 2 \mathrm{~m} \text { ), fence of wire, concrete, } \\
\text { metal (e.g. orchards, vineyards), virtually non-permeable } \\
\text { from the migration point of view }\end{array}$ \\
\hline $\mathrm{K} 2$ & $10-30 \mathrm{~m}$ & Permanent, difficult to penetrate fencing, often electric \\
\hline $\mathrm{K} 3$ & $30-100 \mathrm{~m}$ & $\begin{array}{l}\text { Permanent, non-electric fencing, penetrable with } \\
\text { difficulties }\end{array}$ \\
\hline $\mathrm{P}$ & More than $100 \mathrm{~m}$ & Permeable fencing (e.g. wooden) and temporary fencing \\
\hline PZ & No fencing & No fencing \\
\hline
\end{tabular}

\section{E. Urbanised Areas}

Settlements and scattered urbanised areas represent the key barrier elements within a landscape. Their distribution was derived from the CORINE Land Cover 2006 dataset, and in the case of scattered settlements were all areas of potential migration corridors verified over the dataset of ZABAGED (ČÚZAK 2009). The main element of the barrier effect is the free width of access between settlements. The passageway between continuous settlement structures and individual scattered buildings was distinguished. The free width of passage was seen as the main factor; however, it was necessary to consider the length of it in some cases, too.

Table 6: Classification of Urbanised Areas

\begin{tabular}{||l|l|l||}
\hline \hline Urbanised areas & $\begin{array}{l}\text { Free distance between villages } \\
\text { and towns }\end{array}$ & Free distance between scattered buildings \\
\hline Class & $\begin{array}{l}\text { Continuous settlements, less than } \\
50 \mathrm{~m}\end{array}$ & Continuous settlements, less than $10 \mathrm{~m}$ \\
\hline $\mathrm{K} 1$ & $50-100 \mathrm{~m}$ & Less than $10-30 \mathrm{~m}$ \\
\hline $\mathrm{K} 2$ & $100-500 \mathrm{~m}$ & $30-100 \mathrm{~m}$ \\
\hline $\mathrm{K} 3$ & More than 500 & More than 100 \\
\hline $\mathrm{P}$ & No settlements & No settlements \\
\hline $\mathrm{PZ}$ & &
\end{tabular}

\section{F. Non-forest Areas}

Deforested areas do not represent a priori an assumed major barrier. However, based on spatial extent they can act as a significant barrier for long distance migrations. The distribution of deforested areas was derived from the CORINE Land Cover 2006 dataset (EEA 2009). The main element of the barrier effect is the lack of woodland or other suitable habitat, hence the need to overcome an open area. Two types of landscape are schematically distinguished. These are a fully agricultural landscape without significant scattered vegetation, and a landscape with a significant share of scattered vegetation. 
Table 7: Classification of Non-forested areas

\begin{tabular}{||l|l|l||}
\hline \multicolumn{2}{||l||}{ Non-forested Areas - distance between forested areas } \\
\hline Class & landscape without trees & landscape with scattered vegetation \\
\hline $\mathrm{K} 1$ & More than $5 \mathrm{~km}$ & More than $10 \mathrm{~km}$ \\
\hline $\mathrm{K} 2$ & $5-2 \mathrm{~km}$ & $5-10 \mathrm{~km}$ \\
\hline $\mathrm{K} 3$ & $2-0,5 \mathrm{~km}$ & $2-5 \mathrm{~km}$ \\
\hline $\mathrm{P}$ & Less than $0,5 \mathrm{~km}$ & Less than $2 \mathrm{~km}$ \\
\hline $\mathrm{PZ}$ & Woodland & Woodland \\
\hline
\end{tabular}

The overall distribution of current and potential barriers in the aforementioned types of landscape in the Czech Republic is shown on the map in Figure 6.

Fig. 6: Map of migration barriers

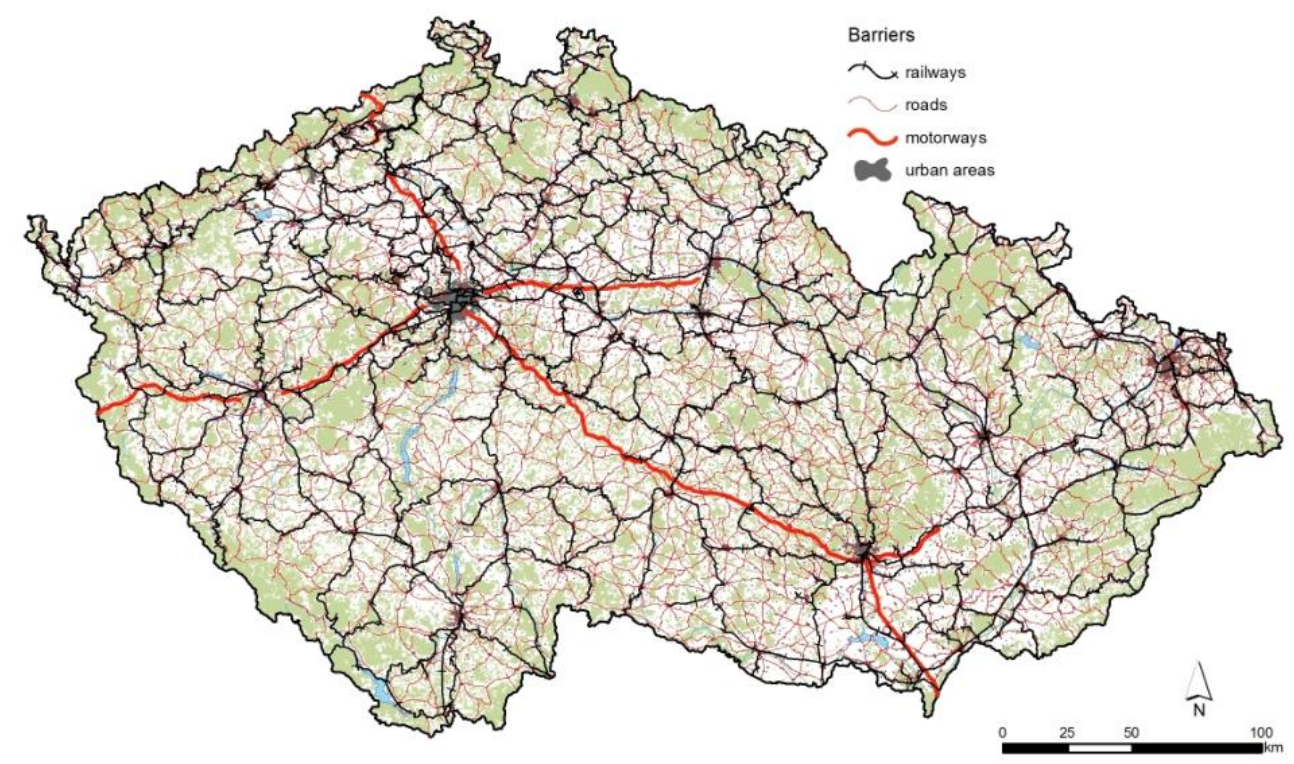

\section{Continuity of migration corridors in neighbouring countries}

An important part of preparation works is also connectivity between the proposed network of migration corridors in the Czech Republic, and the existing or proposed networks of neighbouring countries. The appropriate partner institutions of relevant countries had been officially addressed, but only some were willing to provide relevant data. The network of migration corridors is very precisely designed in Bavaria and Poland; Austria can only offer a framework map of migration directions and only generalised data are available for the whole of Germany. No migration corridors to-date have been officially designed in Slovakia. All data provided were transformed into a matching format and system of co-ordinates. They subsequently became a further foundation for corridor design mainly in the border regions of the Czech Republic. The result of processing the provided data is a map of connectivity between migration corridors in countries neighbouring the Czech Republic (see Figure 7). 


\section{Fig. 7: Map of continuity of migration corridors in Central Europe}

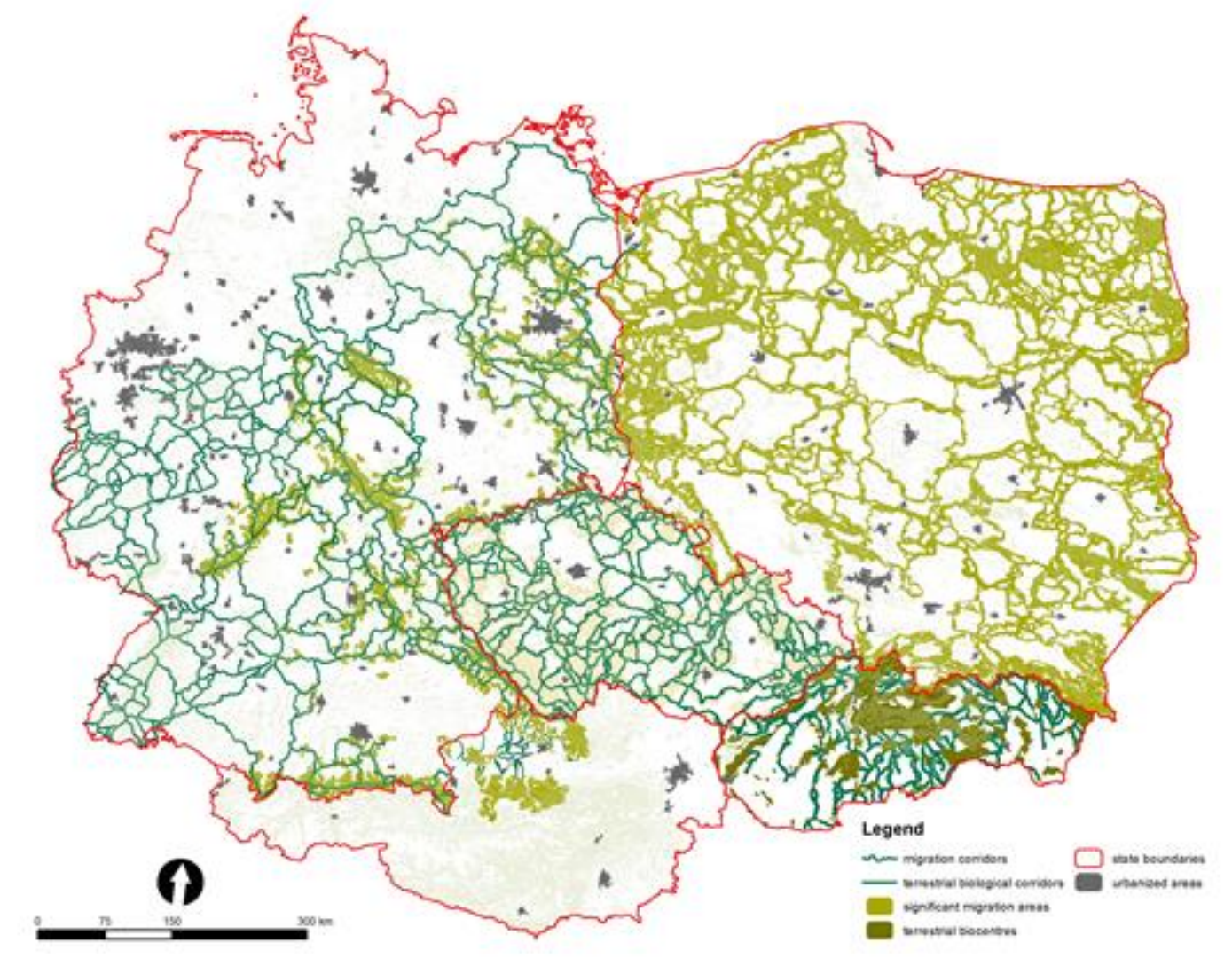

\section{Modelling of potentially suitable habitats of occurrence of target species}

Modelling of potentially suitable habitat for target species is currently among the largely used approaches of conservation biology (e.g. Hirzel et al., 2006, Václavík et al., 2009). For the needs of the design of core areas of real or potential occurrence of species and their connection by corridors, this method has been widely used abroad (e.g. Beier et al., 2008). Therefore, it has been selected for creating support materials for further field mapping. The methods comprise the analysis of input data on distribution of target species (the so-called presence data). The next step was the preparation of datasets describing relevant factors of the environment (the so-called environmental variables) and the final phase means creation of the habitat model itself (the so-called habitat suitability model) (Rottenbery et al., 2006).

Based on the character of the species distribution data, it is necessary to decide which type of model will be applied. Considering the utilisation of Database on species occurrence for nature conservation (NDOP AOPK) it is necessary to select a group of models working with the so-called "presence data", because it is not possible to state with certainty that randomly generated points of pseudo absence would truly represent the locality without the occurrence of the target species. Out of all models working only with presence data, a model based on the calculation of the so-called Mahalanobis's distance was selected, i.e. geometrical distance from an ideal value of the given variable. This 
algorithm is used in the tool of Habitat Modelling, extension of Land Change Modeller for ArcGIS developed in Clark Labs in the USA (Eastman 2009).

Models of potential occurrence of large predators as priority species of large territorial scales were created in the presented project. All available data on the occurrence from the Database on species occurrence for nature conservation for the model species (lynx, wolf, and bear) were transformed into a suitable format. The environmental factors were selected according to their significant influence on species occurrence and dispersal. However, the preparation of environmental variables was restricted by the availability of necessary information. While some basic factors of natural and anthropogenic influence were possible to express easily, many other environmental variables were impossible to express in data or visualise in a GIS environment (e.g. density of prey, anthropogenic disturbance). The following parameters of the environment were selected as the input variables:

- $\quad$ Factors of the abiotic environment: altitude, vertical heterogeneity

- $\quad$ Factors of biotic environment: distance to forest complexes, types of land cover

- Factors of anthropogenic disturbance: distance to road network weighed by their intensity and density, distance to settlements

The output of the model is a grid characterising suitability of the environment, fulfilling the requirements of the target species in the scale from 0 to $100 \%$ (Figure 8) (Hernandez et al, 2008). The results of the habitat suitability model for individual species were compared to the detailed findings regarding the movement of animals monitored by GPS telemetry.

\section{Fig. 8: Map of habitat suitability for the occurrence of Eurasian Lynx (L. lynx)}

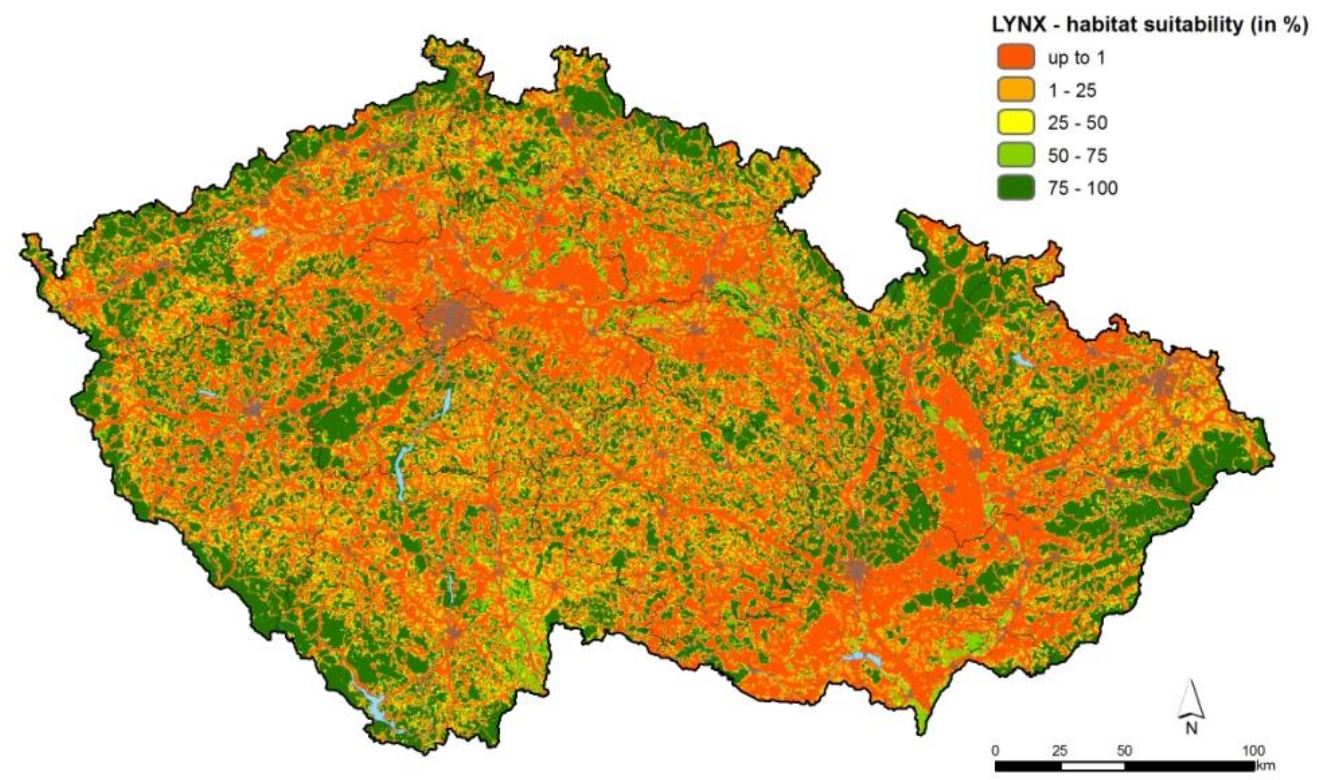


It is obvious from the analysis, that within the home ranges of residential lynx males unsuitable types of habitats are often present; however, the suitable areas create a rather continuous matrix. These outputs were used as a baseline material for delimitation of core zones of actual and potential (semi-) permanent occurrence of target species, and the so called "stepping stones" in the dynamic migration model.

\section{Field survey of position of migration corridors}

Based on the above-mentioned analyses and datasets, the main migration directions were delimited. Their routes were further defined in a GIS environment over the most detailed materials (ZABAGED 1:10.000, ORTOFOTO 2007 - size of a pixel of $0.5 \mathrm{~m}$ ), and a preliminary delimitation of potential conflict places and barriers were simultaneously considered. The conflict places and barriers were also clarified in the field. Each specified corridor route follows the main established migration direction, and uses suitable landscape elements and elements supporting migration as much as possible; it avoids barrier elements or crosses them at the most suitable points. It is useful to incorporate existing permanent legislatively protected elements and areas in landscape from the long-term perspective of protection of the defined corridors. The basic support elements that are considered during the delimitation of a corridor consist of:

- $\quad$ Territorial System of Ecological Stability - TSES - all elements, bio-corridors and bio-centres of interregional and regional level

- Elements of general nature conservation and landscape protection - important landscape elements

- Specially protected areas - large scale protected areas (national parks and protected landscape areas), small scale protected areas (nature monuments, national monuments, national nature monuments and national nature reserve)

- $\quad$ Areas of NATURA 2000 network - SPAs and SACs

The target of corridor delimitation is, however, not just to create connection between existing special protected areas, respectively areas of NATURA 2000 network. Nevertheless, should these areas be suitable for the route of a corridor, it is recommended to use them in that manner. We understand a corridor to be a strip at least $500 \mathrm{~m}$ wide and connecting two key points in the corridor network. A key point is a connecting spot of two or more corridors. The line running through the middle of a corridor is called a corridor axis, which represents the ideal trajectory of movement of a migrating individual. A corridor is divided into segments of variable potential permeability in the sense of the above-mentioned categories of barriers. A segment of a corridor is a part of a minimal length of $200 \mathrm{~m}$ and width of $500 \mathrm{~m}$, characterised by potential permeability that is different from the previous and/or following segment of the same corridor. Every mapped corridor is represented by an individual item in ESRI shapefile layer, for which the attribute table contains all information on the character of permeability in individual segments according to the elaborated methodology. Proposed and in-field confirmed corridors were then classified into individual segments according to the overall permeability. The potential permeability of a segment can be expressed in two quantities: (1) a segment with absence of barriers, i.e. completely barrier-less (completely permeable), (2) barrier segment, i.e. segment with the occurrence of one or more barriers. 


\section{RESULTS}

The delimitated migration corridors correspond in the maximal possible extent with the migration needs of animals, and have a long-term perspective within an evaluated migration direction. Their delimitation is the result of consideration of all available data on occurrence, local dispersion and long distance migration of target species, analysis of landscape structure with utilisation of current and potential future barriers of anthropogenic, as well as natural character. Every migration corridor designed on the basis of analysis of the above-mentioned data was tested in the field; based on this testing, the optimum direction of the axis was proposed together with the solution for eventual critical points. The resulting output covers a set of corridors which is possible to classify as an individual layer among the materials for territorial planning (Figure 9).

\section{Fig. 9: Map of migration corridors}

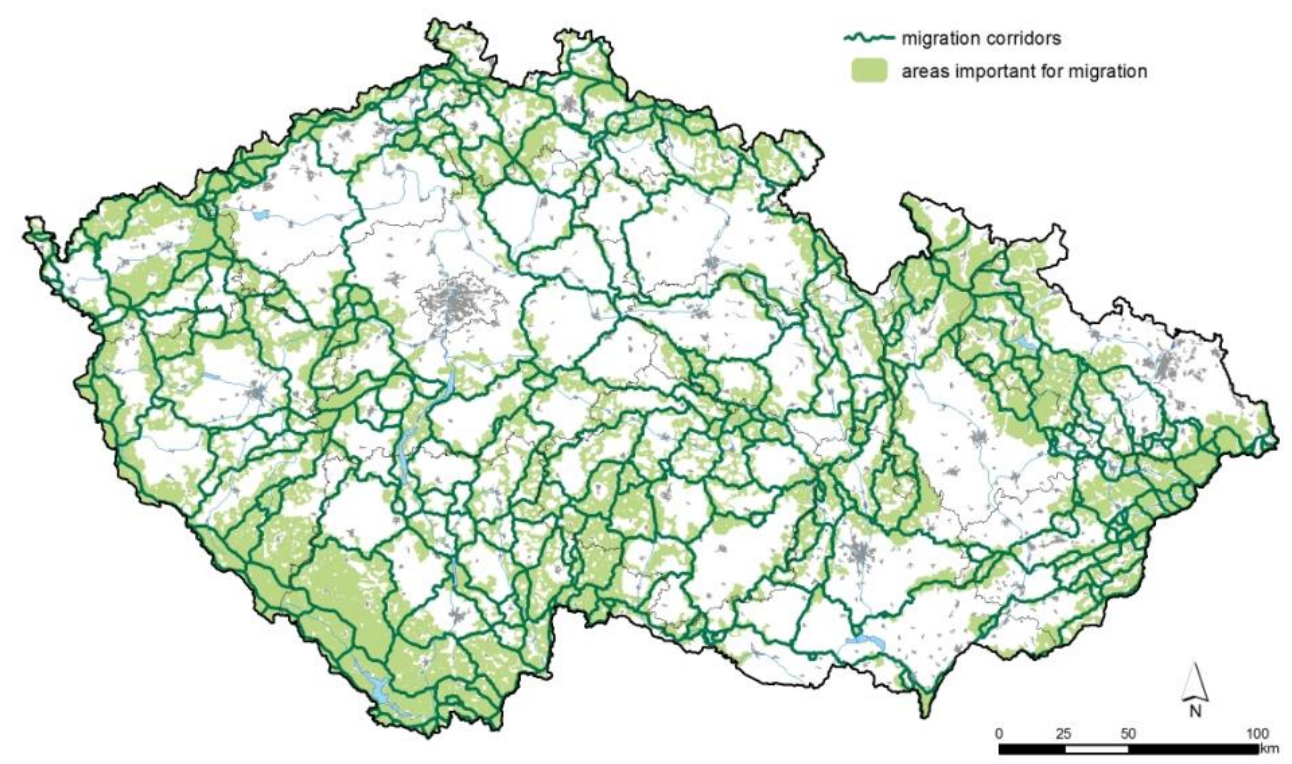

\section{CONCLUSION}

The aim of the article was the introduction of the methodical approach to delimitation of migration corridors of large mammals. The result of the described project is a proposal of national network with connection to the neighbouring countries, the complex territorial protection of which will be necessary to ensure in the future. The team of authors are aware that the introduction of any kind of territorial delimitation is rather difficult at present, and therefore consider its incorporation to one of the existing systems of nature conservation and landscape protection as the easiest solution. The proposed network is closest to the Territorial Systems of Ecological Stability in its character; these however do not solve the problems of long distance migration sufficiently. Therefore, it appears to be optimal to use the opportunity to bring TSES up-to-date for the implementation of this newly elaborated 
network, the legislation protection of which would significantly benefit the migration of large mammals in the Czech Republic.

\section{ACKNOWLEDGEMENTS:}

The article was elaborated thanks to the support of the project SP/2D4/36/08 "Evaluation of Migration Permeability of the Landscape for Large Mammals and Proposal of Protection and Optimisation Measures", launched by the Ministry of the Environment of the Czech Republic.

\section{REFERENCES:}

Anděl, P., Gorčicová, I., Hlaváč, V., Miko, L., Andělová, H., (2005). Hodnoceni fragmentace krajiny dopravou, Metodická př́ručka. Agentura ochrany př́rody a krajiny, Praha, 99 s.

Anděra, M., Červený, J., (2009). Velci savci v České republice. Rozšíření, historie a ochrana. 1. Sudokopytníci (Artiodactyla). Národní muzeum, Praha, 87 pp.

Anděra, M., Hanzal, V., (1995). Atlas rozšíreni savců v České republice. Předběžná verze. I. Sudokopytníci (Artiodactyla), zajíci (Lagomorpha). Národní muzeum, Praha, 64 pp.

Andreas, M. et al. (2007). Vyhodnocení migrační propustnosti krajiny pro velké savce a návrh ochranných a optimalizačních opatření. Projekt Resortního programu výzkumu v působnosti ministerstva životního prostředí" (Kód SP2d4) s počátkem řešení v roce 2008. $33 \mathrm{p}$.

Beier, P., Majka, D.R., Spencer, W.D., (2008). Forks in the Road: Choices in Procedures for Designing Wildland Linkages. Conservation Biology, 22 (4), pp. 836-851.

Bruinderink, G.G., Van Der Sluis, T., Lammertsma, D., Opdam, P., Pouwels, R., (2003). Designing a Coherent Ecological Network for Large Mammals in Northwestern Europe, Conservation Biology, 17 (2), pp. 549-557.

Eastman, J.R., (2009). Idrisi 16.0. The Taiga Edition, Help System. Worcester MA, Clark University- Clark Labs.

Feranec, J., Jaffrain, G., Soukup, T., Hazeau, G., (2010). Determining changes and flows in European landscapes 1990-2000 using CORINE land cover data. Applied Geography, Volume 30, Issue 1, pp. 19-35.

Hlaváč V. et Anděl P., (2001). Metodická príručka k zajištování průchodnosti dálničních komunikací pro volně žijící živočichy. Agentura ochrany př́rody a krajiny ČR, $51 \mathrm{~s}$.

Hernandez P.A. et al. (2008). Predicting species distributions in poorly-studied landscapes. Biodiversity Conservation, 17: pp. 1353-1366.

Hirzel, A. H. et al. (2006). Evaluating the ability of habitat suitability models to predict species presences. Ecological modelling 199 (2006), pp.142-152.

Horskins K., Mather P. B. a Wilson J. C., (2006). Corridors and connectivity: when use and function do not equate. Landscape Ecology 21: pp, 641-655.

Huck, M., Jędrzejewski, W., Borowik, T., Miłosz-Cielma, M., Schmidt, K., Jędrzejewska, B., Nowak, S., et al. (2010). Habitat suitability, corridors and dispersal barriers for large 
carnivores in Poland. Acta Theriologica, 55(2), pp. 177-192. doi:10.4098/j.at.00017051.114.2009.

Iuell, B. et. al. (2003). Wildlife and Traffic: A European Handbook for Identifying Conflicts and Designing Solutions. KNNV Publishers, Brusel, 169 p.

Jongman, R.H.G., (2002). Homogenisation and fragmentation of the European landscape: ecological consequences and solutions. Landscape and Urban Planning, Volume 58, Issues 2-4.

Kramer-Schadt, S., Revilla, E., Wiegand, T., Breitenmoser, U., (2004). Fragmented landscapes, road mortality and patch connectivity: modelling influences on the dispersal of Eurasian lynx. Journal of Applied Ecology, 41: pp. 711-723.

Pimm, S.L., Russell, G.J., Gittleman, J.L. \& Brooks, T.M., (1995). The future of biodiversity. Science, 269, pp, 347-350.

Rottenbery, J.T. et al. (2006). GIS- based niche modeling for mapping species habitat. Ecology, 87(6): pp. 1458-1464.

Schipper, J. et al. (2008). The Status of the World's Land and Marine Mammals: Diversity, Threat, and Knowledge. Science, Vol. 322 no. 5899, pp. 225-230. DOI: 10.1126/science. 1165115 .

Václavík, T., Meentemeyer, R.K., (2009). Invasive species distribution modeling (iSDM): Are absence data and dispersal constraints needed to predict actual distributions? Ecological Modelling 220 (2009), pp. 3248-3258.

Van der Sluis, T., Bloemmen, M., Bouwma, I. M., (2004). European corridors: Strategies for corridor development for target species. Groels, Tilburg, The Netherland, ISBN 9076762-16-3.

Van Wieren, S. E., \& Worm, P. B., (2001). The Use of a Motorway Wildlife Overpass By Large Mammals. Netherlands Journal of Zoology. Retrieved from http://www. ingentaconnect. com/ content/brill/njz/2001/00000051/00000001/art00007. 